\title{
Animots and the Alphabête in the Poetry of Francis Ponge
}

\author{
LAUREL PEACOCK
}

The idea of an animal
patters across the roof

Margaret Atwood, 'Progressive Insanities of a Pioneer'

Animals are a recurring poetic topos; they are anatomized, studied, personified, worshipped, reviled, mystified and addressed by poetry. Because language is one of the many abysses that exist between humans and other animals, they can provoke a crisis of communication, a realization of language's helplessness to communicate across such an abyss. While humans tend to blame and denigrate other animals for failing to speak to us, Michel de Montaigne remarks in his 'Apologie de Raimond Sebond' on the arrogance of blaming all other animals for this language gap, which is equally a human failing; we can no more discern the speech of nonhuman animal than we can control the effects of language (which is a nonhuman agency, after all, that speaks us as we speak it). Communication gaps, furthermore, exist between other animal species-even within this speciesand Jacques Derrida emphasizes in L'Animal que donc je suis that the world is rife with such abysses. Rather than dismissing nonhuman others as inferior based on their perceived lack, why cannot we, clever and inventive animals that we are, be more open to the way other animals call us to adapt language? Cannot poets find a way to innovate with language, to change it in such a way that it can begin to offer a space to nonhuman animals, leading to a more hospitable way of understanding them? Any such innovation can only be an essai, doing the work of poesis, and so it is no coincidence that essays and poems, two forms of writing quite accustomed to innovation, seem particularly well-suited to adaptations that can record at least a trace of nonhuman agencies. In this time of environmental crisis, the humanities need to adapt, drawing on strengths in linguistic innovation, while abandoning thoughtless anthropocentrism, in order to begin to fathom what it is we lose when we lose species diversity.

Jacques Derrida coined the term animot ( $L^{\prime}$ Animal 74$)$ to evoke a multiplicity within the singular term 'the animal' (a term he considers to be the fundamental violence against animals in our language, that enables real violence). As well as registering a multiplicity within its singularity as a homonym of animaux (animals), the term animot can be thought of as marking an animal invasion of 
the word (mot), in which animal otherness animates language. An animot is an animalistic kind of word, and a linguistic kind of animal, attributing animation, even agency, to language. Thus on the level of the word, and even on the level of the letter, animal otherness can be invited into language. Remember that the first letter of our alphabet comes from a representation of an ox, an iconic transcription of an animal into language (imagine the triangular face and the horns in the letter V, upside down). This letter became aleph in the Semitic alphabet, and bet, the second letter, comes from an iconic symbol of a home, or shelter.

In this essay I want to explore some ways language can offer hospitality to animals, through the work of observation, emulation, and poesis. Drawing on what could be thought of as an animated alphabête, poetry that takes into account the language abyss between humans and other animals can shape itself in emulation of these animals as we perceive them, translating this experience into language. In particular, I wish to explore the experiments with nonhuman agency in/of language by French poet Francis Ponge (1899-1988), who has invented ways of treating the subject of the animal in poetry: he constructs habitats out of poems, in order to allow animals to inhabit language. Marianne Moore's 1935 characterization of poetry as 'imaginary gardens with real toads in them' ('Poetry' 267) suggests such a possibility, and a look at some poems by Ponge will reveal another aspect of that line: a wish for poetry that can accommodate the animal's living alterity, impossibly enough, in language.

Ponge wrote what are called 'thing poems', in which an intense meditation on a particular thing brings about a transformation of poetic consciousness, through a contemplation of the thing and its material and linguistic attributes, its silences, and its mode of being. Some of these 'things' are animals, and I would argue that Ponge's animal poems practice a way of thinking about animals that is remarkably sensitive to the problems involved in importing animals (while respecting their alterity) into language. While treating animals as 'things' may seem like mere objectification, things (as opposed to objects) are for Ponge phenomenologically complex; things are not objects in that they are much more than their use-value. They are at once more concrete and less readable than objects. In his 1942 collection Le parti pris des choses (Taking the side of things), Ponge treats things as the subjects (not merely the objects) of his poems. In this and in other collections, the poems treat of a catalogue of garden-variety animate and inanimate 'things' that would tend to get overlooked in their ordinariness. While I only consider 'thing poems' about animals in this essay, Ponge has a range of poetic work that extends his concurrent playfulness with language and openness to alterity to the study/fabrication of a field/prefix, for 
example, in La fabrique du pré (The Making of the Pré). Ponge's poetic attention is absorbed entirely in studying things, which are treated neither as symbols nor as allegories for human concerns, but as interesting in their own alien being.

Ponge's prose poem 'Le Lézard' ('The Lizard') is a good example of his philosophy of animate linguistic difference. The poem begins with a number of metaphors: the titular lizard is a 'chef-d'oeuvre de la bijouterie préhistorique' (Selected Poems 146; a masterpiece of prehistoric jewellery, translations mine) and a 'petit poignard qui traverse notre esprit se tortillant d'une façon assez baroque, dérisoirement' (148; little dagger that traverses our spirit wriggling baroquely enough, ridiculously). The lizard's appearance in the garden represents a traversal not only of the paving stones, but of the spirit or mind. The observer's consciousness is transformed and traversed by this little lizard making such a sharp and sudden unbidden appearance. The metaphors Ponge reaches for come from the human world of art, referring to works of art and art movements, and he makes no attempt to downplay the artificiality of these metaphors; in this way the anthropocentrism of language is highlighted, tellingly, at a moment when language tries (and fails?) to 'capture' a lizard.

As the prose poem continues, it becomes even more self-referential, reflecting on its own process of calling forth the lizard, of providing a suitable habitat. Ponge observes 'un quelquonque ouvrage de maçonnerie' (152; an ordinary work of masonry), and asks, 'A quoi ressemble plus cette surface éclatante de la roche ou du môle de maçonnerie que j'évoquais tout à l'heure, qu'à une page,-par un violent désir d'observation (à y inscrire) éclairée et chauffée à blanc?'(152; What does the shining surface of rock or of mortar that I was just evoking resemble more than a page,- by a violent desire of observation (to write it), brightened and heated to white?). The poem's linguistic and material existence, here, is treated as a construction of a page upon which a lizard might appear. The page, like the masonry, becomes an artificially constructed habitat for the lizard. The poet's 'violent' desire to inscribe an observation of a lizard makes him construct the ideal conditions in which a lizard might appear, disavowing authorial control, however, of the moment and conditions of such an appearance. When the lizard appears, it is not supposed to be transformed by the poem's language, but the poem is transformed by its appearance. Rather than representing the lizard's appearance, words, and then thoughts, act like the lizard to the extent that they become the lizard, take its place:

Qu'un mot par surcroît s'y pose, ou plusieurs mots. Sur cette page, par cette faille, ne pourra sortir qu'un ... (aussitôt gobant tous précédents mots) ... un petit train de pensées grises, - lequel circule ventre à terre et rentre volontiers dans les tunnels de l'esprit. (152) 
That a word moreover alights there, or many words. On this page, through this fault, nothing can get out but a ... (immediately gobbling all preceding words) ... a little train of grey thoughts, - which circle stomach to earth and return gladly into the tunnels of the spirit.

Thoughts, by the end of this poem, can no longer be represented as the detached, bodiless thoughts of Western rationality, but have been given a color and tone, and have learned to appear in the cracks of a wall/page, to dart around like lizards, and to disappear back into the tunnels of the mind. Thoughts gobble words, using the mouth rather than the eyes to incorporate them, to satisfy an appetite.

One of Derrida's key discussions of Ponge's poetry occurs in Signéponge (translated as Signsponge), an unusual work intensely engaged with the question of the signature. The signature is repeatable and quotable, and is subject to the play of language, even as it is meant to fix the singularity of the signatory. Signé Ponge (signed Ponge) can combine to make 'signe éponge' (sign sponge), which makes of the sponge (thing or animal?) a sign and a signature. Derrida discusses Ponge's appropriation of the 'things' of his poems to create his own signature; there is a simultaneous expropriation, however, of the 'thing' in allowing it to exist as other than language. Ponge's poetry operates simultaneously both 'vers le dehors, le retour aux choses mêmes, puis, vers le dedans, le retour au langage, à la question du langage' (23; toward the outside, the return to things themselves, then, toward the inside, the return to language, to the question of language). Encounters with the otherness of things, Derrida observes, intensify Ponge's focus on language.

Ponge's poem 'Les hirondelles, ou, dans le style des hirondelles (randons)' ('Swallows, or, in the style of swallows (escapades)') is briefly discussed by Derrida in relation to the signature; the swallows in this poem practice their signature on the page of the sky, their repeated flight patterns figured as the practiced swoops and flourishes of a signature, as each swallow 'inlassablement se précipiteinfalliblement elle s'exerce-à la signature, selon son espèce, des cieux' (176; tirelessly hastening - infallibly she exerts herself - to the signature, according to her kind, of the skies). The poet addresses the swallows in amazement: 'tu t'écris vite!' (176; you cry out or write yourself quickly!), highlighting for Derrida the paradox of a signature 'réfléchi, retourné vers lui-même, sui-référencié' (Signéponge 133; reflected, returned toward itself, self-referenced). This signature or selfwriting of the swallows occurs 'selon son espèce' (Ponge, Selected Poems 176; according to kind/species), which indicates that it is an idiomatic writing of the species or kind. Far from communicating meaning clearly to the human poetic observer, the signature leaves no permanent written trace (other than, perhaps, in the memory). The birds' tailfeathers (plume: feather and pen) are 'trempée dans l'encre bleu-noire' (176; dipped in blue-black ink), and the observer 
wonders 'Si trace n'en demeure' (176; if no trace remains). The birds have signed with disappearing ink, perhaps, or have chosen blue-black ink that disappears against a blue-black sky. But a trace, however unreadable, remains in the poet's (and the poem's) memory. Ponge gives a sense in this poem of a language proper to the swallows that is nevertheless inaccessible to us, separated by an abyss which is our failing rather than theirs (especially since we are the ones who try and fail to read their language).

The signature of the swallows can only be read in a 'poème bizarre' (176; weird poem), in words made strange by the swallows' writing. The poetic voice exclaims,

Ah! Je le sais par coeur, ce poème bizarre! mais ne lui laisserai pas, plus longtemps, le soin de s'exprimer.

Voici les mots, il faut que je les dise.

(Vite, avalant ses mots à mesure.)(176)

Ah! I know it by heart, this weird poem! but will not leave it, any longer, the care of expressing itself.

Here are the words, I must speak them.

(Quick, swallowing the words one by one).

The impermanent writing of the swallows, which the poet knows by heart (by perception, memory, and love), cannot be left to express itself; it fails to cross the language abyss without translation. Perhaps these lines contain the same despair at the opacity of language with which Virginia Woolf once described hearing the birds singing in Greek (see Dalgarno 32): these birds had a language, but one maddeningly inaccessible to Woolf, who did not know Greek, speaking only the non-sense of madness. Ponge recognizes the need, then, for translation. A good translation is called for, one that allows its own language to be altered by traces of the other('s) language, allowing the voice of the other animal to voice itself as an irruption in the communicative or meaning-conveying or symbolic function of language, marking the spot of interests that are not our own, and maybe not appropriable. The poet offers words that he must say, because there is no other way to translate the bird writing into human language. The poet moved to translation recognizes an insufficiency and a necessity at the same time. Derrida locates this call or imperative to translation (Ponge's 'il faut que'; Selected Poems 176) in the very difficulty of the task, arguing, 'A work that appears to defy translation is at the same time an appeal for translation; it produces translators, and new protocols of translation; it produces other events that make it possible for a translation that does not exist to be produced' (Derrida and Ferraris 16). 
A difficult text (like the 'writing' of the swallows) can call out for its proper translator, and can even generate new methods of translation to deal with the insufficiency of current methods.

Ponge registers not only this imperative to translate the defiantly untranslatable, but also a measure of despair in the failings of translation, despite his best attempts at innovation: 'Leur notation de l'hymne? (Ce serait trop facile.) / Le texte de leur loi? (Ah! ce serait ma loi!)' (178; the notation of their hymn? (That would be too easy.) / The text of their law? (Ah! it would be my law!)). But rather than despairing of any possibility of translation, the poet decides that in order to write a poem translating swallow writing, he must proceed like the swallows, quickly, and must swallow the words as he goes along (here something is gained in English translation). The words must be incorporated (avalée), but also made swallow-like (swallowed), made to behave like swallows as they dive to eat insects or letters.

Following the swallows' flight, the poem engages in an intense 'swallowing' of its words, a linguistic transformation that creates words like ' $l$ 'Horizondelle' (176), 'defined' as swallows on the horizon, made up of the words 'hirondelle' (swallow) and 'horizontal', and then subjected to further transformation away from standard French. In the following passage, swallows inhabit the poem's language:

Tu décris un ambage aux lieux que de tomber

(comme cette phrase).

Puis,-sans négliger le nid, sous la poutre du toit, où les mots piaillent : la famille famélique des petits mots à grosse tête et bec ouvert, doués d'une passion, d'une exigence exorbitantes,

Tu t'en reviens au fil, ou tu dois faire nombre.

(Posément, à la ligne.) (178)

You describe a circumlocution of places to fall

(like this sentence).

Then, - without neglecting the nest, under the beam of the roof, where the words chirp: the scrawny family of little words with big head and open beak, endowed with a passion and a demand that are exorbitant,

You return to the line, or you must make up the numbers.

(Calmly, start a new line). 
Following the movement of the sparrows who land on a (clothes-?) line, a new poetic line (and a new stanza) then begins (in another meaning of the imperative 'à la ligne'). The poem's pace and formal decisions follow the swallows' volition; the sentences, words, and line breaks follow the swallows' flight patterns and behavior. Birds (words) describe a path without landing, and in nests, words (birds) chirp with open beaks for food. Like languages, meanings proliferate, as they follow (swallow) one another. Canadian poet Don McKay (b. 1942) might describe this 'swallowing' of language as an encounter with wilderness in which 'language is experiencing its speechlessness and the consequent need to stretch itself to be adequate to this form of knowing' (McKay30), resulting in a 'slight deformation of human categories, an extra metaphorical stretch and silliness of language as it moves toward the other' (McKay 31). The swallows in their inhabitation of language affect, as well, the subjectivity that can encounter them: 'elles nous jettent en position de spectateurs' (180; they throw us into the [subject] position of spectators).

In L'animal que donc je suis (The Animal That Therefore I Am), Derrida describes this effect of being thrown into a subject position by the gaze of the nonhuman animal in a vignette of being stared at by his cat. In the extensive philosophical disquisition on the matter of 'the animal' that follows this vignette, Derrida develops an ethic of following (suis means both 'am' and 'follow') that continually finds instances in which 'the human' is determined by 'the animal', a category upon which its definition relies. The category of the human is constructed in opposition to 'the animal', and so it follows that the human follows the animal, literally (as in hunting or tracking), and figuratively (as tropes like 'the political animal'). Cartesian humanist thought is allowed to self-deconstruct as relying intrinsically, constitutionally, on a category it attempts to displace.

In tracking 'the animal' through the thickets of philosophy, Derrida encounters aporias that are of significance both to the follower and the followed. Aporias, literally blocked paths, are what happens when we lose the trail, when we have run out of readable traces. And it is exactly such a blocked path that generates the desire to forge ahead, if not with philosophy, which can get us, perhaps, only so far, then with poesis: 'aporicity evokes, rather than prohibits, more precisely, promises through its prohibition, an other thinking, an other text, the future of another promise' (Derrida, Memoires 133).

In 'Les hirondelles', Ponge urges us to use our own prized linguistic precision in the service of understanding and hospitality toward other animals: 'Soyons doncun peu plus humains à leur égard; un peu plus attentifs; consideratifs; sérieux' (180; Be then a little more human on their behalf, a little more attentive; considerate; serious). We are urged to be, then, not less human, not theatrically animalistic, but more human, and more attentive. As Ponge and Derrida demonstrate, in considering exactly what we think we mean by 'human', rather than simply 
trying to leave it behind as a problematic category, we find ourselves following the animal, and innovating with language. Language, after all, like the animal, is a non-human agency that operates according to its own laws, and yet it is one of the ways the human constitutes itself; held up as one of the key cases for human exceptionalism, ironically language precedes and operates to some degree separately from human will, much like the animal (that, therefore, I am and it is). When Ponge invites the animot to transform the act of writing along with our sense of who we are, he is both advocating an ethic of humane perceptiveness, and asking us to approach language, carefully, as the strange animal that it is.

Laurel Peacock is a PhD candidate at the University of California, Santa Cruz. Her dissertation research is on the topic of affect in feminist poetry. She has studied and taught 20th and 21st century poetry, and has written on the role of poetry and poetics in the emergent interdisciplinary fields of animal studies and environmental studies.

\section{Works Cited}

Atwood, Margaret. Selected Poems 1966-1984. Don Mills: Oxford UP, 1990.

Dalgarno, Emily. Virginia Woolf and the Visible World. New York: Cambridge UP, 2001.

Derrida, Jacques and Maurizio Ferraris. A Taste for the Secret. Trans. Giacomo Donis and David Webb. Cambridge: Blackwell, 2001.

Derrida, Jacques. 'Il faut bien manger, ou, le calcul du sujet' Points de Suspension: Entretiens. Ed. Elisabeth Weber. Paris: Galilée, 1992. 269-301.

—. L'animal que donc je suis. Paris: Gallilée, 2006.

- Memoires: for Paul de Man. Trans. Cecile Lindsay. New York: Columbia UP, 1989.

—. Signéponge/ Signsponge. Trans. Richard Rand. New York: Columbia UP, 1984.

McKay, Don. Vis à vis. Moncton: Gaspereau, 2001.

Montaigne, Michel de. 'Apologie de Raimond Sebond.' Essais: Livre 2. Paris: Garnier-Flammarion, 1979.

Moore, Marianne. Complete Poems. New York: Penguin, 1987. 
Ponge, Francis. Le parti pris des choses. Paris: Gallimard, 2004.

- The Making of the Pré (La fabrique du pré). Trans. Lee Fahnestock. Columbia: $\mathrm{U}$ of Missouri P.

- Selected Poems. Trans. C.K. Williams, John Montague and Margaret Guiton. Winston-Salem: Wake Forest UP, 1994. 